УДК004.65:001.92:004.7

Новицька Тетяна Леонідівна

науковий співробітник

Інститут інформаційних технологій і засобів навчання НАПН України, м. Київ, Україна

zhytomyr@meta.ua

Левченко Яна Станіславівна

молодший науковий співробітник

Інститут інформаційних технологій і засобів навчання НАПН України, м. Київ, Україна

ynalevch@meta.ua

\title{
МОДЕЛЬ УПРАВЛІННЯ ІНФОРМАЦІЙНИМИ РЕСУРСАМИ ЕЛЕКТРОННОЇ БІБЛІОТЕКИ НАУКОВОЇ УСТАНОВИ
}

\begin{abstract}
Анотація. У статті розглянуто основні елементи електронної бібліотеки, електронної бібліотеки наукової установи, технологічні процеси електронної бібліотеки, функціональні вимоги до побудови моделі електронної бібліотеки наукової установи. Розглянуто поняття інформаційно-комунікаційна підтримка наукової діяльності, інформаційні системи, метадані, інтероперабельність, моделі, інформаційні ресурси, управління. Уточнено поняття управління інформаційними ресурсами i запропоновано функції управління інформаційними ресурсами. Даються різні підходи до означення поняття метадані. Розглянута модель побудови наукової електронної бібліотеки. Виділено аспекти інтероперабельності. Представлено рівні інтероперабельності. Розглянуто підходи до інтероперабельності електронних бібліотек та описано їх ключові характеристики. Виділено структурні компоненти управління інформаційними ресурсами електронної бібліотеки наукової установи. Запропоновано модель управління інформаційними ресурсами електронної бібліотеки наукової установи.
\end{abstract}

Ключові слова: модель; метадані; інтероперабельність; електронна бібліотека.

\section{1. ВСТУП}

Постановка проблеми. Нині світові темпи створення і розвитку наукових електронних бібліотек зростають. Росте користувацький попит, що говорить про масовість і різноманітність колекцій електронних документів. Інформаційні ресурси (IP) в електронному вигляді, стають більш зручнішими для користування, ніж у паперовому, через простоту отримання їх через всесвітню мережу Internet. Особливо це важливо для науковців, тому що це не тільки зручність, а і швидкість розміщення результатів своєї наукової діяльності на спеціальних сайтах, й ознайомлення з новими передовими науковими відкриттями. Як наслідок така інформаційно-комунікаційна підтримка наукової діяльності дуже важлива. «Інформаційно-комунікаційна підтримка наукової діяльності - це допомога і сприяння суб'єктам наукової діяльності в отриманні й розповсюдженні наукового результату з використанням IКТ»[1, с. 167]. Електронні бібліотеки (ЕБ) є механізмами відображення наукової, освітньої, а також технічної, художньої, публіцистичної та іншого типу відомостей.

«Електронна бібліотека - розподілена інформаційна система, що дозволяє накопичувати, надійно зберігати й ефективно використовувати різноманітні колекції електронних повнотекстових документів, які доступні в зручному для користувача вигляді через глобальні мережі передачі даних»[2, с. 140].Управління інформаційними ресурсами наукової електронної бібліотеки (НЕБ) є складним механізмом ЕБ, який потребує детального вивчення.

Аналіз останніх досліджень i публікацій. Загальнотеоретичні питання використання електронної бібліотеки розглянуті в працях: Спіріна О. М., 
Іванової С. М., Новицького О. В., Тевса Д. П., Петрова В. А., Кузнєцової М. В., Палей Д. Е., Курчинського Д.Н., Смирнова В. Н., Столярова Ю. Н., Кудрявцевої С. П., Колос В.В., Меррей Р. та ін. [2; 4; 5;7; 9; 10]. Над створенням електронної бібліотеки освітнього закладу працювали:Тевс Д. П., Петров В. А., Кузнєцова М. В., Саух В. М., Великжанін Г. В., Фесенко Т. В. [4; 11], наукової установи: Іванова С. М., Спірін О. М., Новицький О. В.,Резніченко В. А., Проскудіна Г. Ю., Кудім К. А., Федотова О. А. [1; 2; 17; 18; 31]. Функціональні вимоги, технологію і архітектуру електронної бібліотеки розробляли: Баркова О. В., Саух В. М., Великжанін Г. В., Фесенко Т. В., Федотова О. А. [6; 11; 18]. Проблему інтероперабельності розглядали: Cayx В. М., Великжанін Г. В., Фесенко Т. В., Stefan Gradmann, Михайлов I. С. [11; 12; 13].

Серед вітчизняних досліджень над питаннями електронної бібліотеки займалися: Іванова С. М., Спірін О. М., Новицький О. В., Резниченко В. А., Проскудіна Г. Ю., Кудім К. А., Овдій О. М., Кудрявцева С. П., Колос В. В., Саух В. М., Великжанін Г. В., Фесенко Т. В., Яцишин А. В. та ін. [1;2; 8; 9;11; 15; 17; 31; 32].

Значний внесок для розвитку електронної бібліотеки зробили зарубіжні фахівці: Burnett K., Kwong Bor Ng, Park S., Stefan Gradmann, Candela L., Gianmaria Silvello, John J. А. [3; 12; 16; 29; 30] та багато ін.

Але проблема побудови моделі управління інформаційними ресурсами електронної бібліотеки наукової установи ще недостатньо вивчена.

Метою дослідження $є$ побудова моделі управління інформаційними ресурсами електронної бібліотеки наукової установи, що може бути використана у процесі розвитку мережі електронних бібліотек галузевих наукових установ.

\section{2. МЕТОДИ ДОСЛІДЖЕННЯ}

Основними методами, що використовувалися в цьому дослідженні, $є$ аналіз ресурсів мережі Інтернету, методичної і спеціальної літератури 3 досліджуваної проблеми, публікацій вітчизняних і зарубіжних учених; основних елементів ЕБ, функціольнальних вимог до побудови ЕБ, моделей ЕБ освітніх закладів, наукових установ, моделей для розв'язання проблеми інтероперабельності мережі ЕБ, функцій управління IP. На основі узагальнення й моделювання побудували модель управління інформаційними ресурсами наукової електронної бібліотеки.

\section{3. РЕЗУЛЬТАТИ ДОСЛІДЖЕННЯ}

\section{1. Поняття інтероперабельності мережі електронних бібліотек}

Відомості й дані в науковій електронній бібліотеці відображаються в статичному або динамічному видах. Це можуть бути публікації, факти, книжки, монографії, статті, ключові терміни, персони, презентації, статистичні дані тощо. Тому інформаційну систему (IC) потрібно розглядати як низку інформаційних об'єктів - набір атрибутів, визначеної семантики, що описує дані в IC. Методом опису інформаційних об'єктів $\epsilon$ метадані. Існує багато трактувань метаданих, усіх їх можна поділити на два підходи: перший - до нього відноситься все, що стосується бібліотечної справи (використання електронних каталогів і т. п.), другий - відноситься до так званих «комп'ютерних наук» (управління даними і т. п.) [3]. Структуровані дані, з певними формалізованими властивостями називають метаданими. Існують окремі вимоги до метаданих для подання їх у науковій електронній бібліотеці. На основі системи метаданих будуються основні технологічні процеси електронної бібліотеки [4]: зберігання, пошук 
інформаційних ресурсів, навігація по сайту електронної бібліотеки, видалення, додавання або зміна інформаційних ресурсів, управління доступом до інформаційних ресурсів і т.д. Отже, інформаційні ресурси складаються 3 метаданих і контенту i зберігаються в архівах — репозиторіях наукової електронної бібліотеки. Проаналізуємо детальніше склад наукової електронної бібліотеки. У роботах $[5$, с. $13-14 ; 6$, с. 116; 7 , c. 235] є схожими основні елементи технологічної моделі електронної бібліотеки, структури ЕБ на яких побудовані основні підсистеми будь-якої бібліотеки, але вони не охоплюють всього. Наприклад [5, с. 13-14]:

1) сховище, що містить ресурси, їх атрибути, взаємодію між ресурсами й атрибутами;

2) зберігання інформаційних ресурсів;

3) доступ до сховища й інформаційних ресурсів.

Окремі науковці розглядають модель наукової електронної бібліотеки, що складається 3 інформаційної складової «сутності» і зв'язків між об'єктами наукової електронної бібліотеки. Ієрархія сутностей складається з фізичного об'єкта (основний об' єкт моделі, у якому зберігаються всі об'єкти даної моделі НЕБ), атрибуту фізичного об'єкта (ідентифікатор фізичного об'єкта, назва, тема, ключові слова, версія, анотація), змісту всіх інформаційних контентів даної моделі і їх атрибутів, класів з відповідними атрибутами і класифікаторів, які використовуються під час задання деяких їх атрибутів [8, c. 28-31].

Стосовно системної архітектури запуску середовища електронної бібліотеки виділяють сервер, репозиторій, базу даних, різні додатки, інтерфейси, утиліти, вебпортал, працівників, користувачів та ін. У [9, с. 20] склад електронної бібліотеки розрізняють за змістом (інформаційні об'єкти будь-якого виду і змісту, будь-якої давності, уже сформовані — видання визначеного періоду, i ті, що тільки поступили до репозиторію - тематичні, хронологічні, предметні, за ознакою цінності, а також великі за змістом електронні колекції, створювані для розвитку людства у будь-якій сфері діяльності), за ступенем доступності (сховища інформаційних ресурсів встановлені і не встановлені у всесвітній мережі, а також резервні копії), за видами надання даних (копії текстових інформаційних ресурсів в електронному вигляді, бази даних, а також оголошення, матеріали конференцій, препринти, повідомлення, публікації, аудіо- і відеоінформація в електронному вигляді, у вигляді цілісних графічних зображень наприклад рукописні матеріали).

До компонентів електронної бібліотеки і процесів ЕБ, відносять: сховища метаданих, методи зберігання ресурсів за ієрархією, криптографування, збірки i журнали в електронному вигляді, збір та розповсюдження інформаційних ресурсів, сканування інформаційних ресурсів, репозиторії, контроль авторських прав, пошук відомостей, автоматизація ЕБ, ідентифікація і безпека, доставка електронних документів, портали, міжбібліотечний абонемент, [10, с. 58-61].

У роботі [11, с. 10] було визначено, що основними завданнями використання електронних бібліотек $є$ інтеграція інформаційних ресурсів і ефективна навігація в них. У проекті Europeana [12] для мережі ЕБ на чільному місці постає проблема інтероперабельності. Для концепції Ініціативи відкритих архівів (OpenArchivesInitiative, OAI) однією з головних цілей і завдань стала розробка й упровадження стандартів інтероперабельності відкритих архівів для ефективного поширення й обміну контентом. У [13] підтримка інтероперабельністі електронними бібліотеками дає можливість взаємодіяти 3 іншими електронними бібліотеками, може виражатись у вигляді обміну даними і метаданими, а також надавати сервіси 3 розподіленого виконання пошукових запитів і підтримки інтеграції гетерогенних ресурсів. Інтероперабельність під час створення IC дозволяє інтегрувати різноманітні джерела 
різних за своєю природою і структурою даних, дозволяючи будувати мережу зв'язків між інформаційними об'єктами [12]. Згідно словника інформаційних технологій (InformationTechnologyVocabulary) інтероперабельність визначається як інформаційний обмін, виконання програми або передавання даних між різними функціональними модулями способом, який не вимагає від користувача практично ніяких знань про унікальні характеристики цих модулів [14, с. 5].

3 огляду на систематичність можна виділити чотири аспекти інтероперабельності:

1) об'єкти інформаційного обміну — це сутності, які насправді повинні бути перетворені в сценаріях взаємодії. Ці сценарії покривають етапи від повного представлення змісту цифрового інформаційного об'єкта до більш простих представлень таких об'єктів, наприклад, через набори атрибутів метаданих. Через ці об'єкти інформаційного обміну користувач чи інша програмна платформа може взаємодіяти з основною системою;

2) функціональна інтероперабельність. Може розглядатися з різних підходів. Це може бути просто обмін і розповсюдження цифрового контенту. Інший підхід дозволяє отримувати функціональне вирішення проблеми об'єднання цифрових об'єктів у загальному рівні інтеграції контенту. На цьому рівні між системною інтеграцією функціональна інтероперабельність вимагає надання користувачам або програмним додаткам можливості взаємодії 3 декількома електронними бібліотеками через уніфіковані інтерфейси. Більш простим 3 технологічної точки зору $є$ створення загальної архітектури і переліку сервісів, які інтегрують контент в єдиній точці;

3) лінгвістична інтероперабельність (багатомовність) можна розглядати двома різними способами: як багатомовні інтерфейси користувача до електронних бібліотек або як динамічні багатомовні методи вивчення об'єктів DigitalLibrary. У другому способі можна виділити три типи підходів: динамічний переклад запиту на різних мовах, динамічної трансляції метаданих відповідати на запити на різних мовах або динамічної локалізації цифрового контенту;

4) технологічні стандарти, що дозволяють різні види взаємодії і мають значну кількість реалізацій, спрямованих на сумісність метаданих, таких як Z39.50/SRU+SRW або методів збору на основі ОАІ-PMH, або підходів, заснованих на веб-службах (SOAP/UDDI), або через стандартизовані в JCR (JSR 170/283) інтерфейси API, а також використання GRID на основі платформ, таких як iRods.

Виділяють два види інтероперабельності: структурну - для різних взаємодіючих IC, які оперують єдиною інтерпретацією структури даних [13]; і семантичну - спільне використання різнорідних інформаційних ресурсів на семантичному рівні [15, с. 15]. Загалом можливо виділити чотири рівні інтероперабельності (рис. 1): технічний, синтаксичний, функціональний та семантичний.

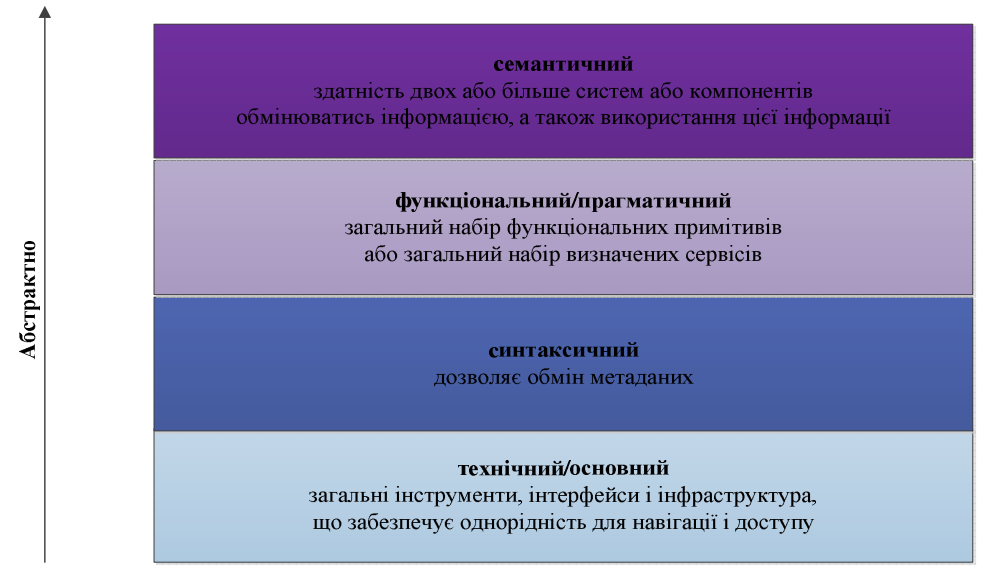

Рис. 1. Рівні інтероперабельності 


\section{2. Моделювання інтероперабельності електронних бібліотек}

Розглянемо підходи до інтероперабельності цифрових бібліотек, що ілюструють характеристики інтероперабельності. $\mathcal{C}$ низка моделей для вирішення проблеми інтероперабельності мережі електронних бібліотек.

Делос Еталонна модель системи управління цифрової бібліотеки (DelosReferenceModelforDigitalLibraryManagementSystems, DELOS) є єдиною моделлю для архітектури, функціональності і технологічних компонентів електронних бібліотек. Основними об'єктами інтероперабельності $\epsilon$ цифрові інформаційні ресурси, які визначаються за ідентифікатором інформації об'єкта.

Є Еталонна модель ЕБ (DigitalLibraryReferenceModel, DLRM) [16] призначена для розробки більш вузьких, спрощених моделей ЕБ, 3 конкретною архітектурою i подальшою їх реалізацією в рамках створюваних інформаційних систем. У цій моделі конкретизують поняття: ЕБ, система ЕБ, система управління ЕБ; моделюють ЕБ для різних категорій користувачів: кінцевий користувач ЕБ, розробник ЕБ, системний адміністратор ЕБ, розробник додатків для ЕБ; узагальнюють основні області, на які розбита модель ЕБ: контент, користувач, функціональні можливості, якість, політики, архітектура і кілька додаткових [17, с. 66].

Як основа для єдиної теорії Електронних бібліотек (DigitalLibraries, DLS) формалізували $5 \mathrm{~S}$ - модель (5S - model), яка використовує набір основних абстракцій: потоки, структури, простір, сценарії та суспільства, що взаємодіють між собою. Інтероперабельність у $5 \mathrm{~S}$ - моделі буде застосована для структурованих наборів даних об'єктів.

ObjectReuseand Exchange (OAI-ORE) є моделлю для збору, накопичення й обміну розподілених веб-ресурсів 3 різними форматами представлення. Об'єктами інтероперабельності $\epsilon$ наукові текстові документи. Функціональна перспектива обмежена декількома функціями пошуку об'єктів, різноманітних маніпуляцій 3 об' єктами та персоналізацій.

Інформаційне середовище JISC (JISCinformationenvironment) надає інтегрований доступ до мережі дослідницького i платформи електронного навчання в Великобританії. Інтероперабельністю ресурсів $\epsilon$ сховища контенту i платформи електронного навчання. Функціональною перспективою є об'єднання сховища контенту і платформи електронного навчання 3 використанням спеціальних служб у всеосяжну модель. У перспективі $\epsilon$ зростання наукового співтовариства, яке підтримує i використовує сховища наукових документів.

Окремо виділяють функціональні вимоги до моделі ЕБ [18].

1. Довготривале, захищене зберігання інформації.

2. Повнота, достовірність походження документа.

3. Історичність інформації.

4. Наявність семантичних анотацій для забезпечення ідентифікації i класифікації ресурсів.

5. Підтримка неоднорідних і слабо структурованих інформаційних ресурсів.

6. Підтримка семантичних взаємозв'язків між інформаційними ресурсами.

7. Представлення інформації користувачу у вигляді вибраним користувачем.

8. Наявність адаптивних сервісів для пошуку інформаційних ресурсів.

9. Підтримка зовнішніх інтерфейсів для вирішення проблем інтероперабельності під час інтеграції із зовнішніми системами.

10. Підтримка роботи із зовнішніми джерелами.

Під моделлю будемо розуміти об'єкт, ідентичний даному за якимись параметрами, за певних умов [19]. Також модель розглядається як особлива форма кодування інформації раніше невідомою. 
Отже, у статті було розглянуто різні структури моделі наукової електронної бібліотеки й функціональні вимоги до наукової електронної бібліотеки.

\section{3. Модель управління інформаційними ресурсами наукової електронної бібліотеки}

Постійно зростаючий обсяг IP вимагає від ЕБ нових рішень для управління даними і надання доступу до них. І в першу чергу це стосується електронної бібліотеки наукової установи. Саме через науковий прогрес розвиваються всі освітні галузі, що $є$ надзвичайно важливим для розвитку держави, у всіх іiї сферах. Наука є стержнем для економічного і соціального розвитку держави.

Для побудови моделі управління інформаційними ресурсами електронної бібліотеки наукової установи визначимось 3 поняттям «управління інформаційними ресурсами». Проаналізуємо основні поняття. У колективній монографії [2, с. 142] «інформаційний ресурс» трактується як «сукупність документів у інформаційних системах (бібліотеках, архівах, банках даних тощо) або сукупність інформаційних продуктів певного призначення, які необхідні для забезпечення інформаційних потреб споживачів у визначеній сфері діяльності».

У великому енциклопедичному словнику «управління - елемент, функція організованих систем різної природи (біологічних, соціальних, технічних), що забезпечує зберігання певної структури, підтримання режиму діяльності, реалізацію їх програм і цілей» [20]. В універсальному словнику-енциклопедії — «це дія на певний процес (об'єкт) з метою забезпечення бажаного його перебігу; спостерігається в біологічних і застосовується у технічних й економічних системах» [21]. У тлумачному словнику української мови - «прийняття стратегічних рішень в міру виявлення потенційних проблем» [22].

Серед науковців цим питанням займалися в основному в галузі державного управління. Так у роботі [23, с. 26-27] вказується, що зараз немає повноцінного пояснення змісту і категоріального визначення поняття управління. Але з існуючих визначень можна зробити висновок про те, що «повне прояснення змісту поняття управління пов'язано з розв'язанням двох завдань. По-перше, із визначенням повного набору суттєвих ознак, що відрізняють процеси управління від інших процесів; подруге, з уточненням самих цих ознак». I розуміють управління «як цілеспрямований інформаційний вплив керуючої підсистеми на керовану підсистему, між якими є зворотний зв'язок».

Визначення поняття «управління інформаційними ресурсами» досліджувалось вченими в галузі інформаційного менеджменту це «оперативне використання інформації як стратегічного ресурсу 3 метою забезпечення конкурентноздатності організації»[24, с. 14].

У роботі [25] «управління інформаційними ресурсами означає: оцінювання інформаційних потреб на кожному рівні й у межах кожної функції управління; вивчення документообігу організації, його раціоналізацію, стандартизацію типів і форм документів, типізацію інформації і даних;подолання проблеми несумісності типів даних;створення системи управління даними тощо».

Відповідно до існуючих визначень управління інформаційними ресурсами це комплекс дій, спрямованих на створення умов для цілеспрямованого, оперативного використання сукупності документів у інформаційних системах або сукупності інформаційних продуктів певного призначення, які необхідні для забезпечення інформаційних потреб споживачів у визначеній сфері діяльності.

Функції управління інформаційними ресурсами: 
1. Цілеспрямований відбір і накопичення IP.

2. Систематизація IP за певними принципами.

3. Створення можливостей оперативного знаходження користувачами необхідної інформації.

4. Передбачення можливості корекції метаданих IP адміністратором ЕБ.

Для можливості взаємодіяти мережі ЕБ, які наприклад, створені на різних технологічних платформах, мають гетерогенні інтерфейси, формати або протоколи обміну інформації та ін., необхідно забезпечення інтероперабельності на всіх рівнях ЕБ. Управління гетерогенними інформаційними ресурсами можливо за умови інтероперабельності на будь-якому рівні ЕБ.

3 метою розвитку мережі ЕБ НАПН України побудуємо модель управління інформаційними ресурсами ЕБ наукової установи (рис. 2).

У результаті дослідження було виділено такі структурні компоненти управління інформаційними ресурсами ЕБ наукової установи: інформаційний об'єкт, джерело інформаційних об'єктів, метадані, колекція ресурсів, представлення інформаційного об'єкту, представлення множини інформаційних об'єктів, управління інформаційним об'єктом, аналіз використання інформаційних ресурсів, політика, якість, пошук, навігація, агрегатор, відношення між інформаційними об' єктами, онтологія, зберігання ресурсів, профіль користувача.

Центральним об'єктом моделі є інформаційний об' єкт. Змістовим представленням інформаційного об'єкта $є$ певний файл, який описаний метаданими. Тобто інформаційний об'єкт перебуває у певному відношенні 3 метаданими. Він може перебувати в певних відношеннях 3 іншими інформаційними об'єктами. Кожен інформаційний об'єкт, який $є$ набором метаданих i файл, може мати певне представлення. Наприклад, для веб-додатків це може бути web-сторінка, яка може мати різний дизайн і різні управляючі елементи стосовно інформаційного об'єкта. Тобто, якщо розглядати інформаційний об'єкт у мережі зв'язаних даних (LinkedData) [26] або у вигляді анотованої сторінки для користувача, чи сторінки для адміністратора, то в кожному з цих варіантів сторінка буде мати різний вигляд. Саме через сторінки представлення інформаційних об'єктів відбувається керування або перегляд даних. Під час керування інформаційним об'єктом у користувача, у якого є певні права, що визначаються його роллю, можуть бути різні можливості, а саме видалення чи редагування інформаційного об'єкта. Під час редагування інформаційного об'єкта користувач повинен дотримуватися певних правил (політиками), що прийняті в електронній бібліотеці. Однією із складових політики оцінювання якості метаданих, детальніше про цю політику розглянуто в [27], є якісні показники інформаційного об'єкту. У першу чергу це стосується якості метаданих. Якщо у користувача є права стосовно рецензування об' єкта, то під час рецензування він повинен перевіряти його контент загалом на відповідність якісним критеріям політики.

Під час використання інформаційних об'єктів користувач отримує доступ через форму пошуку або через переходи по навігаційним посиланням. Наразі користувач знову ж працює з різними представленнями множини інформаційних об'єктів. Об'єкти, які утворюють цю множину, агрегуються з різних джерел. Оскільки агрегація об'єктів має розв'язувати проблеми інтероперабельності, то ці питання у випадку семантичної або структурної гетерогенності інформаційних об'єктів можна розв'язувати за допомогою онтологічного підходу, детальна суть такого підходу розглянута в [28]. Джерелами інформаційних об'єктів можуть бути інші електронні бібліотеки чи та сама електронна бібліотека. 


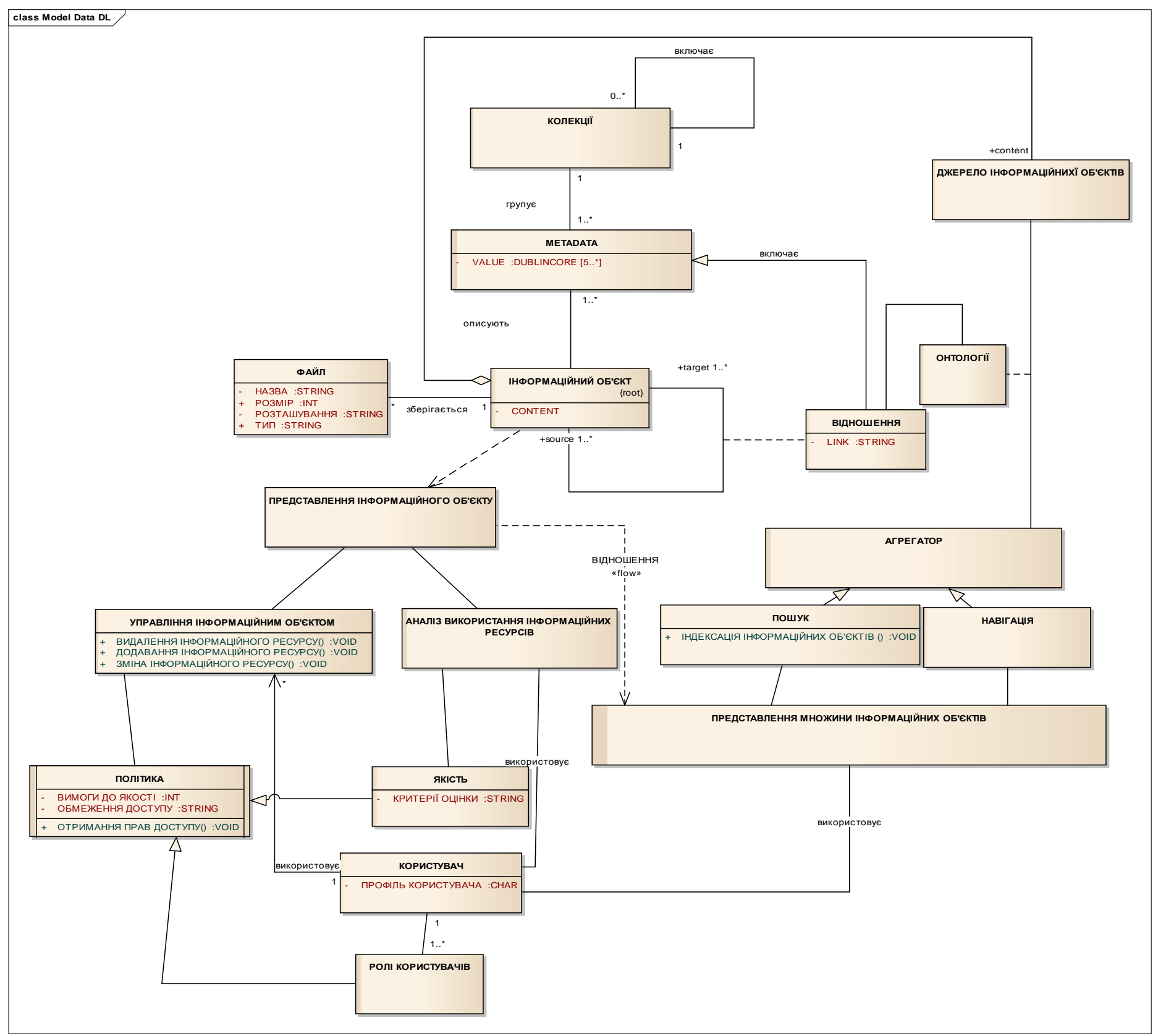

Рис. 2. Модель управління інформаційними ресурсами ЕБ наукової установи

\section{4. ВИСНОВКИ ТА ПЕРСПЕКТИВИ ПОДАЛЬШИХ ДОСЛІДЖЕНЬ}

У ході проведеного дослідження було уточнено поняття управління інформаційними ресурсами, виділено функції управління інформаційними ресурсами й основні структурні компоненти електронної бібліотеки наукової установи, побудована модель управління інформаційними ресурсами наукової електронної бібліотеки, що забезпечує якісне, швидке представлення інформаційного ресурсу зареєстрованому користувачу НЕБ, зручний інтерфейс і ефективну навігацію в ній у разі дотримання прав захисту інформаційних об'єктів. Поряд із цим можливе розмежування прав доступу відповідно до ролі користувача, робота 3 множиною інформаційних об'єктів, які представлені з різних джерел і які за допомогою НЕБ виводяться на сторінці інтерфейсу НЕБ. 
Дослідження процесу формування IP ЕБ з огляду на потреби наукових установ $€$ перспективою подальшого дослідження.

\section{СПИСОК ВИКОРИСТАНИХ ДЖЕРЕЛ}

1. Іванова С. М. Проектування інформаційно-комунікаційної підтримки наукової діяльності на базі системи EPRINTS / Іванова C. М. // Інформаційні технології і засоби навчання : електронне наукове фахове видання [Електронний ресурс]; гол. ред.: В. Ю. Биков. - 2013. — Том 37. — № 5. - С. 166-175. - Режим доступу : http://www.journal.iitta.gov.ua. — Заголовок з екрана.

2. Електронні бібліотечні інформаційні системи наукових і навчальних закладів : монографія /[Спірін О. М., Іванова С. М., Новицький О. В. та ін.]; за наук. ред. проф. В. Ю. Бикова, О. М. Спіріна. - К. : Педагогічна думка, 2012. - 176 с.

3. Burnett K., Kwong Bor Ng, Park S. A comparison of the two traditions of metadata development /J. of the American Society for Information Science. Special issue on integrating multiple overlapping metadata standards [Electronic Resource]. - Vol. 50, Issue 13. - 1999. - Pp. 1209-1217. — Modeofaccess: URL $\quad: \quad$ http://onlinelibrary.wiley.com/doi/10.1002/\%28SICI\%2910974571\%281999\%2950:13\%3C1209::AID-ASI6\%3E3.0.CO;2-Y/pdf.

4. Создание электронной библиотеки образовательного учреждения / [Тевс Д. П., Петров В. А., Кузнецова М. В. и др.] ; под ред. С. Д. Каракозов. - Барнаул : Изд-во БГПУ, 2004. — 129 с.

5. Палей Д. Э. Вариант интеграции цифровой библиотеки и библиографического каталога / Курчинский Д. Н., Смирнов В. Н. // Сборник аннотационных стендових докладов Третьей всероссийской конференции по электронным библиотекам «Электронные библиотеки: Перспективные методы и технологии, электронные коллекции, RCDL'2001», Петрозаводск : Карельск. науч. центр РАН, 11-13 сентября 2001 г. - С. 13-14.

6. Баркова О. В. Использование технологических возможностей АБИС для создания распределенной электронной библиотеки (на примере ИРБИС) / О. В. Баркова // Научные и технические библиотеки. - 2004. - № 3. - С. 113-120.

7. Столяров Ю. Н. Библиотечный фонд правой документации: учебно-практическое пособие / Ю. Н. Столяров. - М. : Либерея, 2003. - 256 с.

8. Резниченко В. А. Концептуальная модель электронной библиотеки / Проскудина Г. Ю., Кудим К. А. // Труды 11-ой Всероссийской научной конференции «Электронные библиотеки: перспективные методы и технологии, электронные коллекции - RCDL'2009», Петрозаводск, Россия, 2009. - С. 2331.

9. Кудрявцева С. П. Міжнародна інформація : навчальний посібник для студентів вищих навчальних закладів / Колос В. В. - К. : Видавничий Дім «Слово», 2005. — 400 с.

10. Меррей Р. Компоненты цифровой библиотеки и их взаимодействие / Меррей Р. // Научные и технические библиотеки. - 2000. - № 3. - С. 56-68.

11. Саух В. М. Технологія і архітектура Semantic Web-порталу електронної бібліотеки ВН3 / Великжанін Г. В., Фесенко Т. В. // Вісник ЧДТУ. — 2011. - № 2. - С. 10-15.

12. Stefan Gradmann. Interoperability Challenges in Digital Libraries [Ectronic Resource]. — Modeofaccess: URL

http://www.dlorg.eu/uploads/Workshop\%20Corfu/Interoperability\%20Challenges\%20in\%20Digital\%20 Libraries Gradmann.pdf. - Title from the screen.

13. Михайлов И. С. Исследование и разработка методов и программных средств обеспечения структурной и семантической интероперабельности информационных систем на основе метамоделей [Електронний ресурс ] : Московский энергетический институт. - Москва, 2008. Режим доступу : http://studdoc.ru/docs/6/index-7501.html - Назва з екрану.

14. IS 14692-1 (1999): Information Technology - Vocabulary,Part 1: Fundamental Terms [LITD 14: Software and System Engineering] [Electronic Resource]. - Mode of access : URL : https://law.resource.org/pub/in/bis/S04/is.14692.1.1999.pdf.

15. Слізаров Д. Підходи до інтеграції неоднорідних інформаційних ресурсів в розвинутих інформаційних системах / Д. Єлізаров // Комп'ютерні технології друкарства. - 2011. — № 26. C. $275 .-$ C. $74-78$.

16. Candela L., Castelli D., Dobreva M., Ferro N., Ioannidis Y., Katifori H., Koutrika G., Meghini C., Pagano P., Ross S., Agosti M., Schuldt H., Soergel D. The DELOS Digital Library ReferenceModel FoundationsforDigital Libraries. IST-2002-2.3.1.12. Technology enhanced Learningand Access to Cultural Heritage [Electronic Resource]. - Mode of access : URL:Version 0.98, December 2007. http://www.delos.info/files/pdf/ReferenceModel/DELOS_DLReferenceModel_0.98.pdf. 
17. Резниченко В. А. О построении моделей електронных библиотек / Резниченко В. А., Проскудина Г. Ю., Кудим К. А., Овдий О. М. // Проблеми програмування. — 2010. — № 4. — С. $60-74$

18. Федотова О. А. Функциональные требования к модели электронной библиотеки по научному наследию : Международная конференция «Математические и информационные технологии, МIT2013» (X конференция «Вычислительные и информационные технологии в науке, технике и образовании») [Електронний ресурс] / Федотова О. А. // Режим доступу до журн.: http://conf.nsc.ru/MIT-2013/ru/reportview/146630.

19. Моисеев Н. Н. Математика в социальных науках / Моисеев Н. . // Математические методы в социологическом исследовании. - М., 1981. - С. 166.

20. Великий енциклопедичний словник [Electronic Resource]. - Mode of access: URL: http://www.vedu.ru/bigencdic/65292/ — Title from the screen.

21. Універсальний словник-енциклопедія [Electronic Resource]. - Mode of access: URL : http://slovopedia.org.ua/29/53411/22602.html. - Title from the screen.

22. Тлумачний словник української мови [Electronic Resource]. - Mode of access : URL : http://uktdic.appspot.com. - Title from the screen.

23. Арістова I. В. Державна інформаційна політика: організаційно-правові аспекти / За загальною редакцією д-ра юрид. наук, проф. Бандурки О. М. : монографія. - Харків : Вид-во Ун-ту внутр. справ, 2000. - 368 с.

24. Матвієнко О. В., Цивін М. Н. Інформаційний менеджмент: опорний конспект лекцій у схемах і таблицях. - К. : Видавничий Дім «Слово», 2007. - 200 с.

25. Митні інформаційні технології: навчальний посібник / [О. Ф. Волик, О. В. Кащеєва, І. В. Дорда та ін.]; за ред. П. В. Пашка.- К. : Знання, 2011. - 391с. [Electronic Resource]. — Mode of access: URL: http://pidruchniki.ws/10020805/informatika/informatsiyni_resursi_organizatsiyi\#297. — Title from the screen.

26. Linked Data [Electronic Resource]. - Mode of access: URL : http://www.w3.org/standards/semanticweb/data.

27. Alice Tani, Leonardo Candela, Donatella Castelli. Dealing with metadata quality: The legacy of digital library efforts /J. Information Processing \& Management[Electronic Resource]. — Vol. 49. — Issue 6. — 2013. - Pp. 1194 - $\quad$ 1205. - Mode of access : URL:http://www.sciencedirect.com/science/article/pii/S0306457313000526.

28. Natalya F. Semantic integration: a survey of ontology-based approaches / J. ACM SIGMOD Record [Electronic Resource]. - Vol. 33. - Issue 4. - 2004. - Pp. 65-70. — Mode of access : URL : http://dl.acm.org/citation.cfm?id=1041421.

29. Gianmaria Silvello. Building a Distributed Digital Library System Enhancing the Role of Metadata [Electronic Resource]. — Modeofaccess : URL: http://www.academia.edu/2868518/. — Title from the screen.

30. John J. A method for interoperable digital libraries and data repositorie / Helly T., Todd Elvins, Don Sutton, David Martinez [ElectronicResource]. - Mode of access : URL: http://www.sdsc.edu/ hellyj/papers/FGCS jjh01.pdf. — Title from the screen.

31. Спірін О. М. Концептуальні засади побудови мережі електронних бібліотек Національної Академії Педагогічних Наук України / Іванова С. М., Новицький О. В. // Інформаційні технології і засоби навчання : електронне наукове фахове видання [Електронний ресурс]; гол. ред.: В. Ю. Биков. 2012. - 5 (31). - Режим доступу до журналу : http://www.journal.iitta.gov.ua. — Заголовок 3 екрана.

32. Яцишин А. В. Електронна бібліотека Національної академії педагогічних наук України як організаційне нововведення / Яцишин А. В., Ткаченко В. А. // Інформаційні технології і засоби навчання: електронне наукове фахове видання [Електронний ресурс]; гол. ред.: В. Ю. Биков. 2011. - Том 26. — №6. - С. 1-16. - Режим доступу : http://www.journal.iitta.gov.ua. — Заголовок 3 екрана. 


\title{
МОДЕЛЬ УПРАВЛЕНИЯ ИНФОРМАЦИОННЫМИ РЕСУРСАМИ ЭЛЕКТРОННОЙ БИБЛИОТЕКИ НАУЧНОЙ ОРГАНИЗАЦИИ
}

\author{
Новицкая Татьяна Леонидовна \\ научный сотрудник \\ Институт информационных технологий и средств обучения НАПН Украины, г. Киев, Украина \\ zhytomyr@meta.ua
}

Левченко Яна Станиславовна

младший научный сотрудник

Институт информационных технологий и средств обучения НАПН Украины, г. Киев, Украина ynalevch@meta.ua

\begin{abstract}
Аннотация. В статье рассмотрены основные элементы электронной библиотеки, электронной библиотеки научного учреждения, технологические процессы электронной библиотеки, функциональные требования к построению модели электронной библиотеки учреждения. Рассмотрено понятие информационно - коммуникационная поддержка научной деятельности, информационные системы, метаданные, интероперабельность, модели, информационные ресурсы, управление. Уточнено понятие управления информационными ресурсами и предложены функции управления информационными ресурсами. Даются различные подходы к определению понятия метаданные. Рассматриваемая модель построения научной электронной библиотеки. Выделены аспекты интероперабельности. Представлены уровни интероперабельности. Рассмотрены подходы к интероперабельности электронных библиотек и описаны их ключевые характеристики. Выделены структурные компоненты управления информационными ресурсами электронной библиотеки учреждения. Предложена модель управления информационными ресурсами электронной библиотеки учреждения.
\end{abstract}

Ключевые слова: модель; метаданные; интероперабельность; электронная библиотека.

\section{INFORMATION RESOURCE MANAGEMENT MODEL OF SCIENTIFIC INSTITUTION DIGITAL LIBRARY}

\author{
Tetiana L. Novytska \\ researcher \\ Institute of Information Technologies and Learning Tools of NAPS of Ukraine, Kyiv, Ukraine \\ zhytomyr@meta.ua \\ Yana S. Levchenko \\ junior researcher \\ Institute of Information Technologies and Learning Tools of NAPS of Ukraine, Kyiv, Ukraine
}

\begin{abstract}
The article deals with the basic elements of an electronic library, digital library of research institutions, digital library processes, the functional requirements for a model of digital library of research institution. It is considered the concept of information and communication support of research activities, information systems, metadata, interoperability, models, information resources management. It was specified the concept of resource management and proposed resource management functions. There are given different approaches to the definition of the concept of metadata and presented the model building of scientific digital libraries, as well as highlighted aspects of interoperability, which are presented by their level, Approaches to interoperability of digital libraries are considered, as well as described their key characteristics. It is emphasized the structural components of resource management for digital library of research institution and the model of resource management for digital library of research institution is proposed.
\end{abstract}

Keywords: model; metadata; interoperability; electronic library. 


\section{REFERENCES (TRANSLATED AND TRANSLITERATED)}

1. Ivanova S.M. Design of intermation and communication support of scientific research on the eprints basis [online] / Ivanova S.M. // Information technology and learning tools. - 2013. — № 5 (37) - S. 166175. - Available from: http://www.journal.iitta.gov.ua. (inUkrainian)

2. The Electronic Library in formation systems of research and educational establishments / [Spirin O.M. Ivanova S.M., Novitsky O.V. thatin.]. - K.: Educational thought, 2012. - 176 s. (inUkrainian)

3. Burnett K., KwongBorNg, Park S. A comparison of the two traditions of metadata development [online] /J. Of the American Society for Information Science. Special issue on integrating multiple over lapping metadata standards. - 1999. - № 13 (50) - S. 1209 - 1217. — Available from: http://onlinelibrary.wiley.com/doi/10.1002/\%28SICI\%291097-4571\%281999\%2950:13\%3C1209::AIDASI6\%3E3.0.CO;2-Y/pdf (in English)

4. Creationofdigitallibraryofeducationalinstitution / [Tevs D.P., Petrov V.A., Kuznecova M.V.andothers]. Barnaul:publishinghouse BSPU, 2004. - 129 s. (in Russian)

5. PalejD.E. Integrationvariantsthedigitallibraryandbibliographiccatalog / KurchinskijD.N., Smirnov V.N. // Collectionannotation POSTERS Thirdnationalconferenceondigitallibraries «DigitalLibraries: AdvancedMethodsand Technologies, DigitalCollections, RCDL'2001», Petrozavodsk: Karelian. ResearchCenter RAN, 11-13 September 2001, - S. 13-14. (in Russian)

6. Barkova O.V.Usingthetechnologicalcapabilitiesof ADIS tocreate a distributeddigitallibrary (with IRBIS) / Barkova O.V. // Scientificandtechnicallibraries. — 2004. — № 3. - S. 113-120. (in Russian)

7. StoljarovYu.N. Libraryfundrightdocumentation: teachingpracticalguide / Yu.N.Stolyarov. - M: Libereya, 2003 - 256 s. (in Russian)

8. Reznichenko V.A.Conceptualmodelofthedigitallibrary / Proskudina G.Yu., Kudim K.A. // Proceedingsofthe 11-thScientificConference«DigitalLibraries: AdvancedMethodsand Technologies, DigitalCollections - RCDL'2009», Petrozavodsk, Russia, 2009 — S. 23-31 (in Russian)

9. Kudrjavceva S.P.Internationalinformation: A manualforstudentsinhighereducation / Kolos V.V. - K.: VidavnichyDim "Word" in 2005. - 400 p. (in Ukrainian)

10. Merrej R. Digitallibrarycomponentsandtheirinteraction / Merrej R. // Scientificandtechnicallibraries. 2000. — № 3. - S. 56-68. (in Russian)

11. Saukh V.M.ThetechnologyandarchitectureofSemantic Web-Portal DigitalLibraryforuniversity / Velykzhanin G.V., Fesenko T.V. // NewsCherkassyStateTechnologicalUniversity. — 2011 — № 2 . — S. 10-15. (in Ukrainian)

12. StefanGradmann. InteroperabilityChallengesinDigitalLibraries [online]. - Availablefrom: URL:http://www.dlorg.eu/uploads/Workshop\%20Corfu/Interoperability\%20Challenges\%20in\%20Digital $\% 20$ Libraries Gradmann.pdf. (in English)

13. 13.Mihajlov I.S.Research and development of methods and software to ensure structural and Semantic in teroperability of information systems based on metamodels. [online]: Moscow Power Engineering Institute. - Moscow, 2008. — Availablefrom:http://studdoc.ru/docs/6/index-7501.html (in Russian)

14. IS 14692-1 (1999): InformationTechnology - Vocabulary, Part 1: FundamentalTerms [LITD 14: SoftwareandSystemEngineering] [online]. - $\quad$ Available from: https://law.resource.org/pub/in/bis/S04/is.14692.1.1999.pdf (in English)

15. Jelizarov D. Approaches to the integration of heterogeneous in formation resources in the developed information systems / Jelizarov D. // Computer technology printing. — 2011. — № 26. — 275 - S.74 - 78 (in Ukrainian)

16. Candela L., Castelli D., Dobreva M., Ferro N., Ioannidis Y., Katifori H., Koutrika G., Meghini C., Pagano P., Ross S., Agosti M., Schuldt H., Soergel D. The DELOS Digital Library Reference Model Foundations for Digital Libraries. IST. — 2002. — 2.3.1.12. Technology enhanced Learning and Access to Cultural Heritage. [online]. — Available from: Version 0.98, December 2007. http://www.delos.info/files/pdf/ReferenceModel/DELOS_DLReferenceModel_0.98.pdf (in English)

17. Reznichenko V.A.The models construction of digital Library / Reznichenko V.A.,ProskudinaG.Yu., Kudim K.A., Ovdij O.M. // Pprogramming problems. — 2010. — № 4 . - S.60- 74 (in Russian)

18. Fedotova O.A.Function alrequirements for a model of the electronic library for scientific heritage: International Conference «Mathematical and Informational Technologies, MIT-2013» (X Conference "Computational and Informational Technologies for Science, Engineering and Education") [online] / Fedotova O.A. // Available from: http://conf.nsc.ru/MIT-2013/ru/reportview/146630 (in Russian)

19. Moiseev N.N.Mathematics in the socials ciences / Moiseev N.N. // Mathematical methods in sociological research. - M., 1981. - 166 s. (in Russian)

20. Great Encyclopedic Dictionary [online]. — Available from: http://www.vedu.ru/bigencdic/65292/ (in Ukrainian) 
21. Universal Dictionary Encyclopedia. - [online]. - Available from: http://slovopedia.org.ua/29/53411/22602.html (in Ukrainian)

22. Dictionary of the Ukrainian Language [online]. — Availablefrom: http://uktdic.appspot.com (in Ukrainian)

23. Aristova I.V. National Information Policy: organizational and legal aspects / For the general editorship of Dr. Law, Prof., prof. Bandurky O.M.: Monograph. — Kharkov: Publishing house Univ.Ext. Affairs 2000. - 368 s. (in Ukrainian)

24. Matvijenko O.V.,Cyvin M.N. Information Management: supporting lecture notes in charts and tables. K.: Publishing House "Word", 2007. — 200 s. (in Ukrainian)

25. Customs in formation technology : Tutorial [online]. / [O.F. Volyk, O.V. Kashhejeva, I.V. Dordathatin.] Foredit. P.V. Pashka. - K.: Knowledge, 2011. - 391s. - Available from: http://pidruchniki.ws/10020805/informatika/informatsiyni_resursi_organizatsiyi \# 297 (in Ukrainian)

26. Linked Data [online]. - Availablefrom: http://www.w3.org/standards/semanticweb/data (in English)

27. AliceTani, LeonardoCandela, DonatellaCastelli. Dealing with metadata quality: The legacy of digital library efforts [online]. / J. InformationProcessing\&Management. — 2013. — № 6 (49). — S. 1194 1205. - Available from: http://www.sciencedirect.com/science/article/pii/S0306457313000526 (in English)

28. Natalya F. Semantic integration: a survey of ontology-based approaches [online] / J. ACM SIGMOD Record. - 2004. - № 4 (33) - S. 65 - 70 - Available from: http://dl.acm.org/citation.cfm?id=1041421 (in English)

29. Gianmaria Silvello. Building a Distributed Digital Library System Enhancing the Role of Metadata [online]. - Available from: http://www.academia.edu/2868518/ (in English)

30. John J. A method for interoperable digital libraries and datarepositorie [online] / Helly T., Todd Elvins, Don Sutton, David Martinez. — Available from: http://www.sdsc.edu/ hellyj / papers / FGCS jjh01.pdf. (in English)

31. Spirin O.M. Conceptual foundations of building a network of digital libraries of the National Academy of Pedagogical Sciences of Ukraine [online] / Ivanova S.M., Novitskiy O.V. // Information technology and learning tools. — 2012. — № 5 (31). — Available from: http://www.journal.iitta.gov.ua (in Ukrainian)

32. Jatsishin A.V. E-library of the national academy of pedagogical sciences of Ukraine as an organizational innovation [online] / Jatsishin A.V.,Tkachenko V.A. // Information technology and learning tools. 2011. — № 6 (26). — S. 1-16. — Available from: http://www.journal.iitta.gov.ua (in Ukrainian) 